\begin{tabular}{|c|c|c|c|c|c|c|}
\hline \multirow{4}{*}{ Impact Factor: } & ISRA (India) & $=3.117$ & SIS (USA) & $=0.912$ & ICV (Poland) & $=6.630$ \\
\hline & ISI (Dubai, UAE & $=0.829$ & РИНЦ (Russia) & $=0.156$ & PIF (India) & $=1.940$ \\
\hline & GIF (Australia) & $=0.564$ & ESJI (KZ) & $=8.716$ & IBI (India) & $=4.260$ \\
\hline & JIF & $=1.500$ & SJIF (Morocco) & $=5.667$ & OAJI (USA) & $=0.350$ \\
\hline
\end{tabular}

SOI: $1.1 /$ TAS
International Scientific Journal
Theoretical \& Applied Science
$\begin{array}{lll}\text { p-ISSN: } 2308-4944 \text { (print) } & \text { e-ISSN: } 2409-0085 \text { (online) } \\ \text { Year: } 2019 \quad \text { Issue: } 06 \quad \text { Volume: } 74 \\ \text { Published: } 27.06 .2019 \quad \text { http://T-Science.org }\end{array}$

Sociological research.
QR - Issue

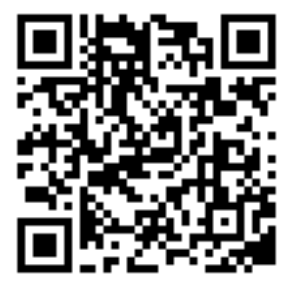

QR - Article

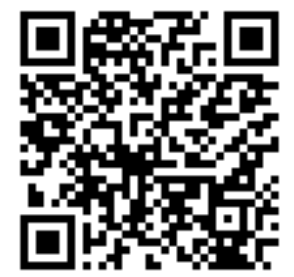

S. T. Nunev

Angel Kanchev University of Ruse

Associate Professor,

Doctor of Science of Social Work, Bulgaria

https://orcid.org/0000-0003-3414-0733

\title{
POSSIBILITIES FOR CONDUCTING SUPERVISION IN THE PRACTICAL TRAINING OF SOCIAL WORK STUDENTS
}

\begin{abstract}
The article presents research on issues of supervision in social work practical training, based on identification of the attitudes of 252 students from University of Ruse, Bulgaria, towards possibilities for its implementation in the conditions of their educational practice in frameworks of four academic years. The content, functional, organizational and structural specifics of supervision of social work students in the conditions of their practical training is analyzed, as well as results of researches in this field. A methodology is used to identifying students' attitudes towards possibilities for realizing supervision in social work practical training, which includes a research tool with certain structural and content components. The results of the research reveal the dominance of the respondents' positive attitudes towards organizational, methodological and operational possibilities for implementation of supervision in social work practical training. A presented is importance of supervision and respondents' preferred model of supervision acquisition of values, knowledge, skills and good professional experience in practical conditions, integrating theory and practice, analysis of problems and situations, reflection, correction of behavior, achievement of change and personal, cognitive and educational development, and formation of professional competence. Highlighted is the contribution of supervision of social work students to improving the quality and effectiveness of their practical training as an important component of their overall educational preparation.
\end{abstract}

Key words: supervision; supervision of social work students; attitudes towards supervision in social work practical training; model of supervision; quality of practical training; student development.

Language: English

Citation: Nunev, S. T. (2019). Possibilities for conducting supervision in the practical training of social work students. ISJ Theoretical \& Applied Science, 06 (74), 535-550.

Soi: http://s-o-i.org/1.1/TAS-06-74-65 Doi: crossef https://dx.doi.org/10.15863/TAS.2019.06.74.65

\section{Introduction}

Supervision is a significant component of social work of help for the client/the social service user and of the social work education for quality preparation of students. It is a process, accompanying the daily professional and educational activity, by which, not only the social workers but also social work students in conditions of practical training acquire values, knowledge, skills and practical experience, receive support to face the challenges of the working environment and achieve change and development in themselves and the client/the social service user. Supervision enables them to explore and analyse the problems and feelings of the client/the social service user, as well as their own difficulties, anxieties, experiences and feelings, and to cope with them in accordance with the professional standards and ethical principles. In addition, supervision is a useful exchange of values, knowledge, skills, ideas, models of professional conduct and good practical experience that allows the supervised practitioners and students to implement and manage their activities in the best interest of the client, its human rights and quality service. In addition, supervision is a useful exchange of values, knowledge, skills, ideas, models of professional conduct and good practical experience that allows the supervised practitioners and students to realise and manage their activities in the best interest of the client, its human rights and quality service. Typical for the supervision is its implementation as a shared responsibility of a supervisor and a supervised, providing efficient support and encouraging competent, responsible, culturally sensitive and based on the principles of antidiscrimination and anti-oppression practice. Its application in the training of social work students is 


\begin{tabular}{|c|c|c|c|c|c|c|}
\hline \multirow{4}{*}{ Impact Factor: } & ISRA (India) & $=3.117$ & SIS (USA) & $=0.912$ & ICV (Poland) & $=6.630$ \\
\hline & ISI (Dubai, UAE & $=0.829$ & РИНЦ (Russia & $=0.156$ & PIF (India) & $=1.940$ \\
\hline & GIF (Australia) & $=0.564$ & ESJI (KZ) & $=8.716$ & IBI (India) & $=4.260$ \\
\hline & JIF & $=1.500$ & SJIF (Morocce & $=5.667$ & OAJI (USA) & $=0.350$ \\
\hline
\end{tabular}

essential for their early professional formation and development and their future professional realization. The acquired by students under the conditions of supervision the values, knowledge, skills, practical experience and dealing of related them thinks, feelings, anxieties and experiences during of the this period of education have a significant impact on their professional competence, values orientation, identity, development and good practice of the future social worker. Consideration of the supervision as an important component of the practical training in social work and substantial factor for quality service of the client/the social service user requires researching the problem for its role and importance in the practical training of social work students $[3 ; 10 ; 11 ; 13 ; 22 ; 28$; $30 ; 37]$. The researches for the social work supervision in Bulgaria are predominant in comparison with its use in the practical training of students in social work. $[29 ; 31 ; 32 ; 34 ; 36]$.

\section{Content, structural and functional aspects of supervision in the practical training of social work students}

The analysis in the research requires clarifying presence of differences between supervision in professional social work and supervision for students under their practical training. Researchers note that such differences exist. They consider supervision of social work students in a relatively uniform background as accentuate on different points, depending on following positions:

A. Structured, interactive and partnership process with certain frames time and includes monitoring, facilitating, training and support of the social work students. Its main purpose is to provide opportunities and conditions for the student to give a significance to their own practice and their observations on the activities of social workers in a given social service or institution for practice. The position of researcher E. Bedoe [4] is that the relationship between the supervisor and supervised social work student are the core of his practical training and are far more different from those in therapeutically oriented models and apprenticeship. Typical of them is that they focus on teaching and learning with features of reflexivity and facilitation. Thus the development of every student in a supportive and yet challenging environment is ensured $[4 ; 17 ; 19$; 39].

B. Learning environment in which social work students realize purposes and tasks of the training for integrating theory with the realities of practice and in which they face and feel the impact of contradictions and conflicts of practice $[16 ; 17 ; 18]$.

C. An important factor that creates conditions for applying the theory into the practical environment [20;24;26;41].

D. Helping social work students to reflect on their experience and providing the opportunity to test and applying the acquired by them values, knowledge and skills, which allows them to optimize their theoretical and practical learning $[17 ; 21]$.

E. Appropriate environment and means for development of the professional self of the supervised student [14].

F. Interaction between the supervisor and supervised student, which contributes to improved relationships with social workers from the social service or institution for practice, clients and community organizations, who allowing students the students are introduced to and learn various models and practices of the social work. Linking the working relationships between the supervisor and the supervised student with the tasks assigned is in favour of both parties [5; 15].

G. Interactions between supervisors and supervised students characterized by intensive interpersonal and supportive relationships and considered as the main means of learning, integrating theory and practice, acquiring practical experience, professional formation and development, student orientation in the implementation of values and ethics of the social work $[37 ; 40]$.

$\mathrm{H}$. The relationship between the supervisor and supervised student is interpreted as a field with the ability to apply the attachment theory. Supervision is conceptualized as informed about attachment ("attachment-informed supervision") and appropriate direction and field of learning. Model of training in the conditions of supervision is based on leading concepts in attachment theory and consider the relationship "supervisor - supervised student" in the context of the working alliance and parallel process. His contribution to increasing the effectiveness of social work learning is recognized $[6 ; 7 ; 8 ; 9 ; 42]$. The presented brief overview reveals that compared to the supervision of social workers, the supervision of students in social work is conceptualized primarily as a training context and supportive and favourable a learning environment. Its goals and tasks oriented towards integration of theory and practice and application of own and acquired within the interaction with the mentors-social workers values, knowledge, skills, activity models and practical experience in certain working conditions. The components of the given context include teaching and learning with features of reflexivity and facilitation, considered as a means for the formation of professional identity and professional development. The environment, in which the practical training of students and related supervision are conducted, is characterized by specific dynamics, difficulties and contradictions in the implementation of professional activities. This enables them not only to get a real idea of the workload and responsibility of the profession, but also to seek the support of a supervisor. The specific in the supervision of students is that in many cases, depending on the adopted concept and model of work, 


\begin{tabular}{|c|c|c|c|c|c|c|}
\hline \multirow{4}{*}{ Impact Factor: } & ISRA (India) & $=3.117$ & SIS (USA) & $=0.912$ & ICV (Poland) & $=6.630$ \\
\hline & ISI (Dubai, UAI & $=0.829$ & РИНЦ (Russia & $=0.156$ & PIF (India) & $=1.940$ \\
\hline & GIF (Australia) & $=0.564$ & ESJI (KZ) & $=8.716$ & IBI (India) & $=4.260$ \\
\hline & JIF & $=1.500$ & SJIF (Morocco & $=5.667$ & OAJI (USA) & $=0.350$ \\
\hline
\end{tabular}

the function and role of the supervisor coincide with those of the controlling and evaluating person in the face of the social worker-mentor and the university lecturer responsible for the training practice. To some extent, this creates tension, anxiety, and hampers of building of trust, partnership, protection and attachment.

The review of publications on the topic reveals that all authors focus on the benefits of the experience gained by students under the supervision of their practical training in social work. Specialists who supervise students during their learning practice should use approaches that are tailored not only to their needs of acquiring of values, knowledge, skills and experience in a particular field, but also to their behavioural and learning models. In this regard, their activities must comply with the following requirements:

a. to create such working relationships in the supervision, as are used in a constructive and pedagogically appropriate manner the types of power relationships and methods of supervision;

b. to achieve a reasonable balance between the capacity to support and encourage students in the process of mastering the vocation of the profession, on the one hand, and the functions of controlling and evaluating students' results, including also joint assessment by certain power positions (social workermentor and university lecturer responsible for practical training), on the other hand;

c. assisting and orientation students in making independent solutions, which are in the interests of their qualitative practical training and professional formation and development;

d. giving focus (direction) and content of the work meeting for supervision in line with the needs to acquire values, knowledge, skills, experience, and the need to overcome the difficulties and barriers encountered in practical training;

e. assisting students in exploring, analysing in depth and assessing objectively specific issues and events, planned and implemented activities, as well as achieving personal progress and development in line with the purposes of the practical training;

f. organizing work meetings on a regular basis for supervision of students, thus carrying into effect a process of continuous learning and complying with the requirements of the methods, standards and ethics of social work, as well as realising on learning through informal contacts and interactions.

Research results have revealed that an important role in the supervision of students has their active participation in the evaluation of their own activity, as in this direction there is a high level of correlation between competence and ability to self-analysis and self-criticism of the student [38]. This allows the evaluation to be formed as a joint result of the activities of the student and the supervisor, standing away from the traditional asymmetric relationships of positions of power between the subject and object of evaluation. When the functions and roles of the supervisor and social worker - the mentor or university lecturer in practice coincides in the evaluation, the negative effect of this overlap is considerably reduced if the students are aware that they have an active role in evaluation their own activities and results. Under such circumstances, the inclusion of the student in the process of evaluation of the results of supervision is an important part of the experience gained in the practical training $[31 ; 32 ; 33$; 34].

The structure and content of the supervision in the practical training of social work students are determined by the following factors:

a. creating a learning environment and atmosphere for conducting work meetings for supervision that stimulate cognitive activity, collaboration, attachment and reflection;

b. using a system of methods of supervision for students, consistent with its purpose, specific orientation, environment for implementation and level of practical training of the supervised;

c. planned and organized implementation, ensuring continuity of the process and contributing to an operative and constructive feedback and achievement of a high quality and effectiveness of practical training and student's development;

d. ensuring an adequate answer to the educational needs of the students in accordance of their level of development, the need to integrate theory and practice and two-way transfer of knowledge and skills from the theoretical and practical field;

e. achieving a value and cognitive change stimulating cognitive activity, reflexivity in knowledge and self-knowledge and pursuit of development and self-improvement;

f. supporting and promoting professional and personal development, integration of the values of the social workers community and formation and development of professional identity.

In the framework of the practical training of the social work students, the supervisor conducts educational interventions, thus providing not only guidance and support, but also encouraging and mobilizing the students and their resources to carry out the assigned tasks with high level of responsibility and quality, to explore in details the problems encountered and cope with the challenges thereof. Supervision of social work students, as a positive and constructively oriented interaction, enables both parties to establish their level of progress in terms of acquisition of values, knowledge, skills and practical experience and better manage the processes of learning, adoption of good practices and integrating the values of the profession.

The supervision in the training of social work students is an insufficiently researched problem. The first thorough and related with this theme research in 


\begin{tabular}{|c|c|c|c|c|c|c|}
\hline \multirow{4}{*}{ Impact Factor: } & ISRA (India) & $=3.117$ & SIS (USA) & $=0.912$ & ICV (Poland) & $=6.630$ \\
\hline & ISI (Dubai, UAI & $=0.829$ & РИНЦ (Russia & $=0.156$ & PIF (India) & $=1.940$ \\
\hline & GIF (Australia) & $=0.564$ & ESJI (KZ) & $=8.716$ & IBI (India) & $=4.260$ \\
\hline & JIF & $=1.500$ & SJIF (Morocco & $=5.667$ & OAJI (USA) & $=0.350$ \\
\hline
\end{tabular}

Europe is conducted in seven universities in countries with different experience and traditions (the Netherlands, Germany, Sweden, Spain, Belgium, Croatia, Slovenia) in 2010 under the project initiative of the network Supervision in Social Work Education in Europe $[1 ; 2 ; 12 ; 22]$. It presents the position that the supervision conducted in the practical training of students in social work is regarded as a method of training and is denoted by the term "student supervision".

According to the researchers on the project, it has an "academic orientation" and differs from the term "supervision in social work" (in particular educational supervision) relating to professional social work [25]. The research is oriented towards the search for answers to questions that are related to the reasonable inclusion of supervision in the curricula and educational programs of the specialty and solving organizational and methodological issues in the implementation of supervision in the practical training of social work students. The results from the research show that most university programs in social work at the bachelor's degree in Europe offer supervision to support students in their practical training. Nevertheless, student's supervision in their practical training on social work is interpreted in a different way. Discrepancies relate mainly to the planning, organization and the way it is included in the curricula and educational programs. Despite the outlined situation, the academic teams in all universities are unanimous that it is necessary and useful the use of supervision for the practical and comprehensive training of students and the results that must be achieved.

The supervision of social work students is characterized by the following functional particularities:

a. giving an appropriate response to the educational needs of students and creating conditions for cognitive and practical professional formation and development;

b. using reflection and accumulation of reflexive experience; creating conditions for professional and personal development of the future social work specialist;

c. defining a clear and well-structured time frame in relation to the number of regular meetings with a specific purpose and for a given time period.

In organizational, structural and methodological aspect, the supervision in practical training of social work students includes the following basic stages:

1. Initial stage, which consists in introducing the student/students with the bases for practice (Department for Social Assistance, Department for Persons with Disabilities; Department for Child Protection; municipal Department for Social Activities; various types of Social Services, etc.) and their staff, the social worker performing the functions of the supervisor and the group for supervision.
2. Main stage that represents the real part of the process of the supervising of the student/students in their social work practical training and in accordance with the adopted models, methods, organizational, structural and timing frame. It is realized through a series of work meetings, which are initiated jointly by the supervisor and the student/students.

3. Final stage, which is associated with the completion of the training in a given practical field for a certain time period and conducting of an individual and group supervision in purpose:

a. identifying of main problematic issues and fields; analysing an implemented activity in terms of achievements and shortcomings;

b. joint assessment of the conducted supervision and determination of measures and opportunities for development;

c. outlining of future measures to cope with them;

d. working on the implementation of a smooth transition from the given base and field of social work practical training to the next in the training for the semester or the academic year.

Attitudes of the social work students towards the conduct of supervision in the practical training

In Bulgaria, there are no legal provision, standards and methodology for conducting supervision in practical training on social work students in the specialties in the professional field "Social work". Supervision of students' social work learning practice is not used in all universities in the country and it is implementation out in accordance with their position on its function, role, content and methodological provision. This leads to the deprivation of social work practical training from a very important component and to a significant deficit in the following aspects:

a. forming a positive attitude towards supervision in the social work learning practice and future professional activity;

b. optimal use of the opportunities of supervising in social work learning practice for the acquisition of values, knowledge, skills and good experience, development and accelerated identification with the profession and community of social workers;

c. encouraging social work students to make best use of the supervision in their future professional activity to improve the quality and effectiveness of serving social services users and to achieve professional development.

\section{Purpose of the research}

Identifying the students' attitudes of the Social Work Bachelor's and Master's degree programs towards conduct of supervision in their practical training as one of the important factors for active inclusion in activities, acquisition of values, 


\begin{tabular}{|c|c|c|c|c|c|c|}
\hline \multirow{4}{*}{ Impact Factor: } & ISRA (India) & $=3.117$ & SIS (USA) & $=0.912$ & ICV (Poland) & $=6.630$ \\
\hline & ISI (Dubai, UAI & $=0.829$ & РИНЦ (Russia & $=0.156$ & PIF (India) & $=1.940$ \\
\hline & GIF (Australia) & $=0.564$ & ESJI (KZ) & $=8.716$ & IBI (India) & $=4.260$ \\
\hline & JIF & $=1.500$ & SJIF (Morocco & $=5.667$ & OAJI (USA) & $=0.350$ \\
\hline
\end{tabular}

knowledge, skills, experience and achieve educational and professional development.

The object of the research is the social work students' supervision in the social work practical training and the subject - are its content, functional, organizational and technological, cognitive, valuable, motivational, reflexive, educational and qualification elements and characteristics of social work students' supervision. The analysis of the research results and the conclusions thereof is expected to contribute to the creation of the suitable educational environment for conducting of social work students' supervision.

\section{Participants in the research}

The research is implemented with 225 students from the Social Work Bachelor's (88\%) and Master's (12\%) degree programs at University of Ruse from 2014 to 2018 (4 academic years, totalling 8 semesters: 120 weeks or a total of 30 months). The students from both social work programs during these years are a total 252. Quantitative information reveals that $89.29 \%$ of all social work students participate in the research by their own choice. The sample of the research is unintentional and random (randomized). It provides equal opportunities for all students from Social Work Bachelor and Master Degree to fall into it. The choice of the non-representative small sample is determining by the factors: A. Cognitive orientation of the study and specific nature of interactions in pedagogical and a professional-practical environment with certain content and methodological features. B. Focusing on interactions and the resulting students' attitudes to supervision in their social work learning practice. C. Specificity of the functioning of the students' supervision in the context of the social work learning practice as a pedagogical interaction and an environment for assisting and improving the quality and effectiveness of the practical training. D. Searching a solution to a problem of significant cognitive, educational and professional character, which is essential for integrating theory and practice, enhancing the quality of education, students' developing and preparing them for professional realization. E. Specificity of the activity studied in the context of the social work practical training and the related processes and dynamics. F. Purpose of the research and possibility to work effectively with the sample.

\section{Methods}

The research is implemented with constructing by the author tool "Questionnaire for researching attitudes of students from the Social Work Bachelor's and Master's degree programs towards conduct supervision in the social work practical training". The questionnaire is approbated, validated and included 7 subscales with a total of 25 items. It is anonymous and is filled in online on the website of the specialties of professional direction "Social Work" at the University of Ruse (https://socialaffairsru.weebly.com/). Respondents' answers to attitudes towards using supervision in their social work learning practice are reported on the five-point Likert scale. The research is conducted through informed consent and is voluntary and anonymous.

In the instructions for filling out the questionnaire are presented explanations of the used concepts. When using the concept "supervision", we mean supervision with students during their social work practical training, implemented in its individual and group form and through a specific system of methods. When using the concept "supervisor", we mean the performance of their functions by the university lecturer in charge of the educational practice or by the basic specialist-social worker (mentor), depending on the adopted conception and the decision made. Supervised is the student who participates in the supervision during the social work learning practice.

\section{Analysis of the research results}

1. Subscale 1A (Item A1; Item A2). Organization and planning of the implementation of supervision of students in the social work practical training.

The subscale includes items related to the determination of the attitudes towards the implementation of supervision in respect of planned implementation and availability of a certain organization. It consists of the elements: prior written placing of issues, setting of day and time, preparation of both parties for the working session, stages of the work meeting, level of active participation, taking notes, recording in the journal for learning practice; conducting of supervision at least once in each base for learning practice. In synthesis, they constitute an important factor in the formation of the students' positive attitudes towards the implementation of supervision in the social work practical training. The analysis of the results in the subscale presents a relative share of responses for positive attitudes of $83.60 \%$ on average for all items (Table 1 ). 


\begin{tabular}{|c|c|c|c|c|c|c|}
\hline \multirow{4}{*}{ Impact Factor: } & ISRA (India) & $=3.117$ & SIS (USA) & $=0.912$ & ICV (Poland) & $=6.630$ \\
\hline & ISI (Dubai, UAE & $=0.829$ & РИНЦ (Russia & $=0.156$ & PIF (India) & $=1.940$ \\
\hline & GIF (Australia) & $=0.564$ & ESJI (KZ) & $=8.716$ & IBI (India) & $=4.260$ \\
\hline & JIF & $=1.500$ & SJIF (Morocce & $=5.667$ & OAJI (USA) & $=0.350$ \\
\hline
\end{tabular}

Table 1. Relative values of the respondents' answers - Subscale 1A.

\begin{tabular}{|l|c|c|c|}
\hline \multirow{2}{*}{ Item } & \multicolumn{2}{|c|}{ Relative values of the respondents' answers depending on their orientation $-\%$} \\
\cline { 2 - 4 } & non-affirmative answers & neutral answers & affirmative answers \\
\hline Item A1 & 5.50 & 11.00 & 83.50 \\
\hline Item A2 & 4.50 & 11.90 & 83.60 \\
\hline Mean value & 5.00 & 11.45 & 83.55 \\
\hline
\end{tabular}

The dominant positive orientation of the positions expressed by the students reveals their attitudes and expectations to participate in supervision, which is characterized by appropriate organization, planning, realization, accordance with methodological requirements and creation of the environment and conditions for acquisition of values, knowledge, skills and professional experience. In synthesis, they contribute to quality and effective social work practical training. Respondents' responses on items in the subscale expressing negative attitudes of respondents have a relative share of $5 \%$. Quantitative information reveals the presence of a certain part of respondents who have not overcome the negative attitudes towards the organizational, activity and resultative components of the supervision. Neutral attitudes are expressed by an average of $11.45 \%$ of the respondents, which is an indicator for taking an action to better inform the students about the importance and benefits of their participation in supervision and for their practical and complete social work training. The total relative share of an average $16.45 \%$, formed of the negative attitudes and neutral positions, demonstrates the need for further work on improving the organization and planning of the supervision; motivating and encouraging the students to actively participate in the supervision in their practical training in social work as its necessary and important component.
2. Subscale $2 B$ (Item B1; Item B2; Item B3; Item $B 4)$. Creation of the suitable environment and conditions for supervision in the practical training of students in social work, which facilitate collaboration, active acquisition of knowledge, skills and experience, the integration of theory and practice and management of the processes of learning and acquiring of practical experience based on the basis of achieved progress and development.

Essential meaning to the realization of the constructive and positive oriented working relationship between supervisor and supervised student, with contribution to the efficient and effective process of practical training have the certain factors. The cooperation and mutual exchange of ideas and solutions between the person executing the function of a supervisor and the supervised student towards active acquisition of knowledge, skills and experience, integration of theory and practice and implementation of uncontroversial and fruitful two-way transfer from both fields. And also the determining the level of progress and development in terms of knowledge, skills and practical experience and more successful management of the process of learning and acquisition of good learning practices. The presented factors are reflected in Subscale 2B and the prevailing part of respondents' responses (on average $89.20 \%$ of subscale items) express positive attitudes towards them (Table 2).

Table 2. Relative values of the respondents' answers - Subscale 2B.

\begin{tabular}{|l|c|c|c|}
\hline \multirow{2}{*}{ Item } & \multicolumn{3}{|c|}{ Relative values of the respondents' answers depending on their orientation $-\%$} \\
\cline { 2 - 4 } & non-affirmative answers & neutral answers & affirmative answers \\
\hline Item B1 & 4.20 & 6.90 & 89.00 \\
\hline Item B2 & 1.40 & 8.30 & 90.40 \\
\hline Item B3 & 0.50 & 9.60 & 90.00 \\
\hline Item B4 & 2.30 & 10.00 & 87.70 \\
\hline Mean value & 2.10 & 8.70 & 89.20 \\
\hline
\end{tabular}

This relative share is the second highest among the seven subscales and correlates to a certain extent with the expressed students' positions and attitudes in Subscale 1A, Subscale 3C and Subscale 7G (Table 1, Table 2, Table 3, Table 7). Supervision of the presented features requires the creation of an appropriate organization and environment, planning, methodological provision, high level of responsibility of the supervisor and supervised student. Its important function is also to create conditions that promote the value, cognitive, personal and professional development of social work students. Assumptions about the high values of the relative shares of the declared neutral item positions for the subscale as a 


\begin{tabular}{|c|c|c|c|c|c|c|}
\hline \multirow{4}{*}{ Impact Factor: } & ISRA (India) & $=3.117$ & SIS (USA) & $=0.912$ & ICV (Poland) & $=6.630$ \\
\hline & ISI (Dubai, UAE & $=0.829$ & РИНЦ (Russia & $=0.156$ & PIF (India) & $=1.940$ \\
\hline & GIF (Australia) & $=0.564$ & ESJI (KZ) & $=8.716$ & IBI (India) & $=4.260$ \\
\hline & JIF & $=1.500$ & SJIF (Morocce & $=5.667$ & OAJI (USA) & $=0.350$ \\
\hline
\end{tabular}

whole (average $8.70 \%$ ) and their dominance over the relative shares of the negative attitudes (average $2.10 \%$ ) may be explained by the existence of some barriers in the realization of social work learning practice (Table 2). Part of the barriers may be associated with insufficient awareness and student anxiety concerning on the power positions of the university lecturer responsible for learning practice and the social worker-mentor who perform the function and role of supervisor and at the same time evaluating their activity in the learning practice. In this regard, the analysis of the results highlights a need from an accessible explanation of the students about the differences between the functions and roles of the supervisor as assessors of the learning practice. It is also important improving the style of interaction and communication between the supervisor and the supervised student, as well as the possibilities of the supervision for their qualitative and effective practical training.

3. Subscale $3 C$ (Item C1; Item C2; Item C3). Providing conditions in the supervision in practical training, which facilitate and develop the analysis of the problems and situations and the active feedback, reflection in supervising students and their ability for critical thinking. By means of the Subscale 3C, the students' attitudes regarding the possibilities of supervising to activate of the analytical-critical and the reflexive components in their practical training are identified. The relative share of the positive attitudes expressed by the respondents' responses has an average value of $86 \%$ for the subscale and allows highlighting a comparatively favorable trend in certain aspects (Table 3):

a. providing opportunities for analysis of emerging problems and situations and for maintaining of an effective feedback between the supervisor and the supervised;

b. application of methods and approaches that stimulate self-analysis in the supervised by providing an opportunity to assess the current level of practical training, level of satisfaction with it in personal, educational and in perspective in professional plan; the need to change the current situation, the use of means to achieve a new level of development that corresponds to the purposes and tasks of the practical training and of the personal and professional aspirations of the student;

c. developing a critical thinking ability in the supervised student by identifying difficulties and problems in practical training in a timely manner; collecting and evaluating information from different sources in accordance with the specifics of the problems and from different points of view; generating ideas and showing creativity; analysing and evaluating decisions and related actions and behaviour.

Table 3. Relative values of the respondents' answers - Subscale 3C.

\begin{tabular}{|l|c|c|c|}
\hline \multirow{2}{*}{ Item } & \multicolumn{3}{|c|}{ Relative values of the respondents' answers depending on their orientation $-\%$} \\
\cline { 2 - 4 } & non-affirmative answers & neutral answers & affirmative answers \\
\hline Item C1 & 0.9 & 7.80 & 91.30 \\
\hline Item C2 & 4.10 & 13.20 & 82.70 \\
\hline Item C3 & 1.30 & 14.70 & 84.00 \\
\hline Mean value & 2.10 & 11.90 & 86.00 \\
\hline
\end{tabular}

The relative share of the positive attitudes expressed by the respondents in the presented content elements is in the fourth position by value among the seven subscales in the research tool (Table 3). With the highest value, this difference it is at elements for provided supervisory capabilities to analyse problems and contradictory work situations, to maintain effective feedback between the supervisor and the supervised supervisor in a manner and in environment that stimulate the self-analysis in the supervised student. The quantitative information presented, the outstanding dynamics, and their analysis reveal the need for focussing the efforts of the performers and the role of supervisors in the learning practice on the reflexive component of the supervision, creating favourable conditions for its active inclusion and use by the students in its realization. Confirmation of the proposed measures is the low values of the relative shares of the declared negative positions by the particular items (in the range of $0.9 \%$ to $4.10 \%$ ) and the high relative share of the neutral positions (in the range of $7.80 \%$ to $14.70 \%$ ). There is reveal the existence of certain deficits and taking action to further work to positivity the attitudes of a certain part of the students (Table 3). At the highest level this need is expressed in item $\mathrm{C} 3$, presenting the capabilities of the supervision to develop students' critical thinking abilities in realization learning practice in social work and in the overall learning process.

4. Subscale 4D (Item D1; Item D2; Item D3; Item D4). Providing an opportunity at the supervision in the practical training of social work students for the development of sensitivity to their own and those of the clients thoughts, feelings, actions and behavior and a readiness for change and development.

Essential importance for the implementation of an effective supervision in the social work practical training is the formation of a working relationship 


\begin{tabular}{|c|c|c|c|c|c|c|}
\hline \multirow{4}{*}{ Impact Factor: } & ISRA (India) & $=3.117$ & SIS (USA) & $=0.912$ & ICV (Poland) & $=6.630$ \\
\hline & ISI (Dubai, UAE & $=0.829$ & РИНЦ (Russia & $=0.156$ & PIF (India) & $=1.940$ \\
\hline & GIF (Australia) & $=0.564$ & ESJI (KZ) & $=8.716$ & IBI (India) & $=4.260$ \\
\hline & JIF & $=1.500$ & SJIF (Morocce & $=5.667$ & OAJI (USA) & $=0.350$ \\
\hline
\end{tabular}

which enables the students to understand their own and those of the clients inner world (thoughts, feelings and experience), actions and behavior and to strive for change and development. The Subscale 4D considered together with the Subscale $1 \mathrm{~A}$ and Subscale $6 \mathrm{~F}$ are one of the characterized by larger ranges. It encompasses items, which related to the determination of students' attitudes towards the following features of the supervisory working alliance:

a. raising the sensitivity of the supervised student to their own and those of the clients/ social service users thoughts, feelings, experiences, actions and behavior and formation positive attitudes towards supervision, thereby providing the opportunity for it to be used in future professional realization as a practicing social worker;

b. creating conditions, helping and encouraging the supervised student to awareness of the situation that including in this type of activity is a factor in accepting the need for receiving of support in cases of conflicts, difficulties, problems and dilemmas in practical training and in future professional activity;

c. building of the base on the experience acquired from supervision in the practical training of a new vision of action, constructive attitude towards practical training, and determination to make corrections in its to related activities and behavior if necessary;

d. forming of a sustainable motivation to use the possibilities of supervision through a regular and conscious involvement and conviction in the need to objectively assess their own learning and practical work to achieve change and development.

The subscale includes items that relate to one of the most important methodological aspects of supervision in social work practical training adjustment to our own and client's thoughts, feelings, actions and behaviors, professionally conscious use of supervision, objective assessment of their own activity, striving for change and development. The analysis of the results presents reveals positive attitudes at an average $85.23 \%$ of respondents' responses for all subscales, which is one of the high relative values of this type of attitudes (Table 4). The presented quantitative information highlights the importance, which the students give through their assessments, of the working relationship with the presented personal, interpersonal, interactive and reflexive focus. The highest relative share of preferred responses for positive attitudes was identified in Item D2 (89\%) and Item D4 (87.60\%). In a content aspect, they include certain elements. The first of these is determination and using supervision in the social work practical training as providing the possibility to accept the need to receive support in cases of problems and dilemmas in practical training and future professional activity. The second element is associated with consideration of regular participation in supervision as a factor for the formation of sustainable motivation and objective evaluation of learning-practical activities. The high relative share of positive attitudes in given items is an accompanied by low values of relative shares of expressed negative attitudes and declared neutral positions (Table 4).

Table 4. Relative values of the respondents' answers - Subscale 4D.

\begin{tabular}{|l|c|c|c|}
\hline \multirow{2}{*}{ Item } & \multicolumn{3}{|c|}{ Relative values of the respondents' answers depending on their orientation $-\%$} \\
\cline { 2 - 4 } & non-affirmative answers & neutral answers & affirmative answers \\
\hline Item D1 & 1.80 & 15.60 & 82.60 \\
\hline Item D2 & 0.50 & 10.50 & 89.00 \\
\hline Item D3 & 1.40 & 16.90 & 81.70 \\
\hline Item D4 & 1.80 & 10.60 & 87.60 \\
\hline Mean value & 1.37 & 13.40 & 85.23 \\
\hline
\end{tabular}

Neutral positions stated by respondents (13.40\%) prevailed over negative attitudes (1.37\%) and their total relative share was $14.77 \%$ (Table 4 ). Our assumptions and analysis are associated with the view that the given situation is determined primarily of the insufficient knowledge of the components of the supervision in the practical training and not by rejecting them. The presented quantitative and qualitative analysis requires the university professor and the mentor-social worker active additional work with the students in certain fields: accessible and detailed informing and clarifying of the importance of supervision their qualitative practical training and motivation and active involvement in properly organized, systematically implemented and effective supervision. The results of respondents' responses to positive attitudes towards the supervision in their practical training in Subscale 4D in a quantitative and qualitative aspect correlate with those from Subscale 2B and Subscale 3C (Tables 2, 3, 4). This underlines the importance of forming a positive, constructive and partner-oriented supervisory relationship, which is characterized by motivating students to participate in supervision; searching for opportunities to overcome 


\begin{tabular}{|c|c|c|c|c|c|c|}
\hline \multirow{4}{*}{ Impact Factor: } & ISRA (India) & $=3.117$ & SIS (USA) & $=0.912$ & ICV (Poland) & $=6.630$ \\
\hline & ISI (Dubai, UAE & $=0.829$ & РИНЦ (Russia) & $=0.156$ & PIF (India) & $=1.940$ \\
\hline & GIF (Australia) & $=0.564$ & ESJI (KZ) & $=8.716$ & IBI (India) & $=4.260$ \\
\hline & JIF & $=1.500$ & SJIF (Morocco) & $=5.667$ & OAJI (USA) & $=0.350$ \\
\hline
\end{tabular}

the difficulties encountered; active learning and acquisition of important practical experience; development of the reflection and the critical thinking in the social work practical training and the supervision, realized in its context.

5. Subscale 5E (Item E1; Item E2; Item E3). Implementation of supervision in the practical training of students in social work under a particular model a university professor; mentor-social worker; jointly by the university professor and the mentor-social worker). The quality and effectiveness of supervision in the practical training of social work students is to a considerable extent determined by the specialist who implements it. It is perceived in a certain ways by supervised students depending on the position occupied and the performed functions, education, qualification and quality of professional practice (university professor, a mentor-social worker). The grounded choice of the aforementioned professional persons for supervisors, as well as an appropriate model of supervision in practical training are main factors in identifying the overcoming of some barriers to the interaction between supervisor and supervised student, building trust, partnership, productivity, dealing with the effect of the influence of power positions on the supervisor (trainer and assessor). Failure to address these barriers has an impact on the direction of working meets between supervisor and supervised students and the attitude of students to supervisors and supervision. To a certain extent, these attitudes influence not only the activity, the analytic, the critique, the motivation to learn in the conditions of the practical training, but also the perception of the supervision as necessary for their change and development in the educational and professional- practical aspect. Subscale 5E includes items to identify students' attitudes towards the person (s) which perform (s) or the function and the role of supervisor in social work practical training. There are three types of implementation of supervision by certain persons:

a. university professor, which guides, the learning practice;

b. mentor-social worker from a social service, department or institution in whose conditions the is realized learning practice;

c. university professor and a mentor-social worker which are partners in the implementation of the supervision and allocate the functions, roles and responsibilities depending on the specifics of the situation and the educational needs of the students.

The analysis of the results reveals expressed positive attitudes on an average at $77.67 \%$ of respondents' responses for the items of the subscale, which is the lowest relative share of this type of attitude in the all subscales in the research tool (Table $5)$. The quantitative information presented and its qualitative analysis give us reason to express an assumption not only of contradictions and doubts, whit which students face in clarifying their vision of the role and function of supervising a particular person in their practical training. The responsibility and competence of the teaching team in defining an appropriate model of supervision is also important. Compared to 2014-2015 the relative share of the expressed positive attitudes has risen by $10.36 \%$ (from $67.31 \%$ to $77.67 \%$ ) and this reveals certain progress in addressing the contradictions and unexplained positions [33].

Table 5. Relative values of the respondents' answers - Subscale 5E.

\begin{tabular}{|l|l|l|l|}
\hline \multirow{2}{*}{ Item } & \multicolumn{2}{l|}{ Relative values of the respondents' answers depending on their orientation -\% } \\
\cline { 2 - 4 } & non-affirmative answers & neutral answers & affirmative answers \\
\hline Item E1 & 12.00 & 14.10 & 73.90 \\
\hline Item E2 & 9.50 & 14.50 & 76.00 \\
\hline Item E3 & 3.70 & 13.20 & 83.10 \\
\hline Mean value & 8.40 & 13.93 & 77.67 \\
\hline
\end{tabular}

For the period 2014-2015, the neutral positions and negative attitudes of the respondents were approximately equal $16.66 \%$ and $16.03 \%$, and their overall relative share was the highest in the entire questionnaire $-39.69 \%$. After this period, the average value of the relative share of negative attitudes decreases almost twice $(8.40 \%)$, and that of the declared neutral positions reduced to $13.93 \%$. The quantitative information presented and its qualitative analysis reveal taking action and achieving a positive result. Nevertheless, there is still a need from filling certain deficits concerning persons that would perform their functions and role of supervisor in a way characterized by efficiency and contribution to the qualitative practical training of social work students. There is a need to continue the activity of selecting and approving a model of supervision in the practical training of students, which to the highest degree meets certain requirements:

a. the specifics of the practical training environment;

b. competencies and experience of the mentorsocial worker and the social service staff;

c. students' educational needs and attitudes towards a supervisor figure which is appropriate and in the interests of quality and effective practical 


\begin{tabular}{|c|c|c|c|c|c|c|}
\hline \multirow{4}{*}{ Impact Factor: } & ISRA (India) & $=3.117$ & SIS (USA) & $=0.912$ & ICV (Poland) & $=6.630$ \\
\hline & ISI (Dubai, UAI & $=0.829$ & РИНЦ (Russia & $=0.156$ & PIF (India) & $=1.940$ \\
\hline & GIF (Australia) & $=0.564$ & ESJI (KZ) & $=8.716$ & IBI (India) & $=4.260$ \\
\hline & JIF & $=1.500$ & SJIF (Morocce & $=5.667$ & OAJI (USA) & $=0.350$ \\
\hline
\end{tabular}

training; dynamics and efficiency of the process of acquiring values, knowledge, skills and experience, integrating theory and practice, overcoming contradictions, difficulties and problems, and compensate of deficits.

When presenting an opportunity for realization of the supervision by the university professor of learning practice, $73.90 \%$ of respondents' responses expressed positive attitudes. This is the lowest relative share of such a type of attitude not only in the items in the analyzed subscale, but also among the subscales in the research tool. By value, the relative share of negative attitudes $(12 \%)$ is less than the stated neutral positions (14.10\%) and together they form an overall share of $26.10 \%$, which is one of the highest in the given subscale and regarding of the other subscales. The quantitative and qualitative analysis of the results of this item aims at a more careful and in-depth understanding of the expediency of using the given model of supervision and taking measures to overcome the impact of the power positions of the university professor in the realization of the function and the role of supervisor. In the subscale presents a second possibility to realize out supervision with social work students, such as the function and role of supervisor are implementation by the mentor-social worker in the social service, department or institution. The mentor is also an important figure in practical training, which has a certain power positions as a trainer and assessor.

Compared to the previous item and the model presented in it, the share of positive attitudes expressed by respondents' answers is higher $-76 \%$. The relative value of neutral positions $(14.50 \%)$ predominates significantly above the value of negative attitudes $-9.50 \%$ (Table 5). Although their total share of $24 \%$ is lower than the previous one, it also raises the question of choosing a student supervision model that is based on careful and indepth analysis, argumentation and conform to power positions of the performer of the functions and role of supervisor namely the mentor-social worker in the social service, department or institution.

The third option regarding on the subject of realizing supervision in the social work practical training on presents in a separate item a model of partnership between the university professor and the mentor-social worker (co-supervision). The relative share of the positive attitudes towards this model, expressed by respondents' answers, which a relative share of $83.10 \%$ (Table 5), which is highest compared to the previous two options for realization of supervision separately of certain persons (university professor and mentor-social worker). Compared to the previous two articles, the negative attitudes expressed were reduced three to four times $(3.70 \%)$, as the rest part of respondents' replies are concentrated in the neutral positions sector - $13.20 \%$ (Table 5). Quantitative and qualitative data analysis allows us to present a suggestion of a trend more clearly and categorically expressed positive attitudes but accompanied by a certain relative share of neutral positions. The analysis reveals that over $2 / 3$ of the sample of respondents is aware of the importance and accepts the need to use a model of co-supervision, appreciates its importance in creating environment and conditions for a positive oriented working relationship, partnership, fruitful learning, acquiring of values, knowledge, skills and practical experience, integrating theory and practice, reflection, change and development. In this regard, our assumptions are that during the implementation of supervision in the conditions of practical training and on the base of the experience gained during the research period concerning the advantages and disadvantages of the separate models of supervision, the students had the opportunity to establish the advantages of this model and to form a certain position. In support of our assumptions, we can note that the model of cosupervision is characterized by: a wider and more balanced basis for student support and learning; more channels of constructive, analytical, reflexive and critical communication, providing the student with a wealth of relationships with professionals with mutually complementary competencies and experience and demonstrating a positive-oriented professional co-operation model [35]. The student has the opportunity to use the resources, both of individual co-supervisors, as well as the formed system of general resources and constructive and partner relationships.

Comparison of quantitative and qualitative analysis results for the three Subscale 5E items allows to present summaries of preferences and positive attitudes of students to the model of co-supervision, which have their argumentation. It connects with a specific to the model characteristics such as partnering, balancing of power positions of supervisors, a deployed communication network, and a broader basis for support and professional analysis, positions and suggestions of the two supervisors on issues, educational needs, potential and opportunities for progress and development of social work students in the conditions of their practical training.

6. Subscale $6 F$ (Item F1; Item F2; Item F3; Item F4). Style of interaction used by the supervisor in the working supervision relationship. The style of interaction of the supervisor with social work students in the conditions of supervision is an essential factor for its effective realization. Included in Subscale $6 \mathrm{~F}$ items are related to identifying students' attitudes towards the style of interaction of the supervisor and its main features in the context of the working relationship:

a. providing certain forms of support to realize the appropriate behavior of the supervised student;

b. building a trust relationship and using a peaceful, businesslike and a respectable tone of 


\begin{tabular}{|c|c|c|c|c|c|c|}
\hline \multirow{4}{*}{ Impact Factor: } & ISRA (India) & $=3.117$ & SIS (USA) & $=0.912$ & ICV (Poland) & $=6.630$ \\
\hline & ISI (Dubai, UAE & $=0.829$ & РИНЦ (Russia & $=0.156$ & PIF (India) & $=1.940$ \\
\hline & GIF (Australia) & $=0.564$ & ESJI (KZ) & $=8.716$ & IBI (India) & $=4.260$ \\
\hline & JIF & $=1.500$ & SJIF (Morocce & $=5.667$ & OAJI (USA) & $=0.350$ \\
\hline
\end{tabular}

communication when carrying out monitoring, control and placement of requirement for changing the inappropriate behavior;

c. timely reaction, implementing consistent and methodologically appropriate actions when necessary correction of a supervised student behavior;

communication and realization of activities and interactions with supervised students characterized by constructiveness, positive orientation, culture sensitivity and other differences (e.g. gender, age, disability, sexual orientation, etc.) and realization of non-discriminatory behavior.

Regarding to purpose and content, the subscale relates with identifying students' attitudes towards one of the most important technological components of supervision in their practical training, which concerns the use of a professionally grounded interaction style by the supervisor in the context of a working relationship with a supervised student. Data analysis reveals pronounced positive attitudes at an average $86.75 \%$ of respondents' responses for all subscale items, which is the third largest of the value relative share of this type of attitude in the research tool (Table 6). Established relative shares respondents' responses for positive attitudes are high in their values not only in the given subscale, but are also among the highest in the subscales of the questionnaire. The quantitative information and its analysis make it possible to highlight the position of the students about the importance of a positive, supportive, and oriented towards achieving changes in behavior and activity, methodologically appropriate, sensitive to differences and non-discriminatory interaction style of the supervisor with the supervised student. Neutral positions $(10.70 \%)$ dominate over the negative ones
$(2.55 \%)$, as their total relative share $(13.25 \%)$ being one of the relatively low in the research tool (Table 6).

The presented situation and related with her dynamics can be interpreted as an indicator of the insufficient knowledge of the characteristics of the interaction style of the supervisor by some respondents rather than such as lack of expectations for such or rejecting them. In this direction, it is necessary to include students in supervision in the context of their social work practical training to be combination with appropriate forms of information and their stimulation to active inclusion in supervision with a positive, constructive, supportive and tolerant style of interaction. Data analysis reveals, that in quantitative and qualitative aspect and with regard to the clearly outlined trend of dominance of positive attitudes, the subscale results correlate with the results of the second, third and seventh subscales. The presented information is possible interpret as evidence of the relationship between the adequate style of interaction between the supervisor and the supervised student with the following elements:

a. constructively and positively oriented communication and partnership;

b. maintaining effective feedback and motivating to solve tasks;

c. managing and supporting learning processes, integrating theory and practice, learning good practice and assessing progress; stimulating cognitive, personal and professional development;

d. analyzing controversies, difficulties and problems, and coping with them;

e. acceptance of the values of the professional community; development of reflection and the critical thinking of the student.

Table 6. Relative values of the respondents' answers - Subscale 6F.

\begin{tabular}{|l|c|c|c|}
\hline \multirow{2}{*}{ Item } & \multicolumn{3}{|c|}{ Relative values of the respondents' answers depending on their orientation -\% } \\
\cline { 2 - 4 } & non-affirmative answers & neutral answers & affirmative answers \\
\hline Item F1 & 3.20 & 11.50 & 85.30 \\
\hline Item F2 & 1.40 & 7.80 & 90.80 \\
\hline Item F3 & 2.30 & 11,50 & 86.20 \\
\hline Item F4 & 3.30 & 12.00 & 84.70 \\
\hline Mean value & 2.55 & 10.70 & 86.75 \\
\hline
\end{tabular}

7. Subscale $7 G$ (Item G1; Item G2; Item G3; Item G4; Item G5). Inclusion of the supervised to the values and traditions of the profession and creating conditions for the development of values, cognitive, professional and personal development.

The successful realization of supervision in social work practical training is determined to a significant extent by the following factors, representing a significant part of the sub-subscale: a. creating conditions for inclusion to the values and social work traditions and the social workers professional community;

b. supporting and promoting of the value, cognitive, personal and professional development;

c. stimulate, mobilize and motivate to solve assigned tasks with high level of responsibility and quality of results;

d. orienting in the research and analyzing the difficulties and problems encountered and overcoming the challenges generated by them. 


\begin{tabular}{|c|c|c|c|c|c|c|}
\hline \multirow{4}{*}{ Impact Factor: } & ISRA (India) & $=3.117$ & SIS (USA) & $=0.912$ & ICV (Poland) & $=6.630$ \\
\hline & ISI (Dubai, UAE & $=0.829$ & РИНЦ (Russia & $=0.156$ & PIF (India) & $=1.940$ \\
\hline & GIF (Australia) & $=0.564$ & ESJI (KZ) & $=8.716$ & IBI (India) & $=4.260$ \\
\hline & JIF & $=1.500$ & SJIF (Morocce & $=5.667$ & OAJI (USA) & $=0.350$ \\
\hline
\end{tabular}

In synthesis, the presented factors have an important contribution both to the formation of positive attitudes of students towards the use of supervision in their practical training as well as to their development in a valuable, cognitive, personality and professional aspect. In parallel, they have a long-term significance with their motivating influence for participation in supervision of future professional realization and for identifying with the community of social workers.

Data analysis of all items in the subscales reveals positive attitudes with an average of $89.58 \%$ of respondents' replies, which is the largest relative share of positive attitudes in the research tool (Table 7). Through the positions expressed, the students present their expectations and preferences for participation in supervision in their practical training, which is characterized by clear value orientation, focus on supporting and promoting the cognitive, personal and educational development contributing to the professional identification. At the highest extent this is expressed in item G3 and item G5 (Table 7), linked in content plan with the contribution of the supervision for the personal and professional development, research and analysis of problems encountered and handling the challenges posed by them. Negative attitudes in the subscale are stated at a small relative share of respondents' responses (on average, 1.62\%), as in Item G5 such answers are not expressed (Table 7). Neutral position is presented on average at $8.80 \%$ of the answers, which is the second lowest relative share of this type of position in the subscales of the questionnaire. Neutral position presents an average $8.80 \%$ of the respondents' answers, which is the second lowest relative share of this type of position in the subscales of the questionnaire. The general relative share of answers related to negative attitudes and respondents' answers without expressing an opinion is $10.42 \%$, and has the lowest value among subscales in the research tool (Table 7). Notwithstanding this result and the established sustained positive trend and minimal dynamics, our position is associated with the need for further work to stimulate active inclusion in supervision and optimal use of its possibilities as an important component of practical training.

Table 7. Relative values of the respondents' answers - Subscale 7G.

\begin{tabular}{|l|c|c|c|}
\hline \multirow{2}{*}{ Item } & \multicolumn{3}{|c|}{ Relative values of the respondents' answers depending on their orientation -\% } \\
\cline { 2 - 4 } & non-affirmative answers & neutral answers & affirmative answers \\
\hline Item G1 & 1.40 & 10.50 & 88.10 \\
\hline Item G2 & 3.20 & 9.70 & 87.10 \\
\hline Item G3 & 1.30 & 7.80 & 90.90 \\
\hline Item G4 & 2.20 & 8.70 & 89.10 \\
\hline Item G5 & 0 & 7.30 & 92.70 \\
\hline Mean value & 1.62 & 8.80 & 89.58 \\
\hline
\end{tabular}

8. Additional questions about the expected results from the use of supervision in the practical training of social work students

The research tool includes outside the subscales additional questions, through which students are given the possibility to present the own positions for the prognosticate result from the use of supervision in their social work practical training. Expressed attitudes to achieve a significant positive result in $76.89 \%$ of the respondents' are established. The relative share of responses with attitude of insignificant effect was $16.89 \%$, and at $2.22 \%$ of the answers there is a doubt as to the achievement of a certain result, an extreme negative position is presented in $1.78 \%$ of the responses. Without opinion on the matter are $2.22 \%$ of the respondents' answers. The general relative share of answers without opinion, of answers with a doubt in achieving a certain result and of answers with expressed negative position, is of low value - a total $6.22 \%$. The data analysis allows to indicate the presence of minimal dynamics and a clearly outlined positive trend in students' attitudes for the expected good results from the use of supervision in their teaching practice realized in different fields of social work. Parallel to the positive aspects presented in the quantitative and qualitative analysis, it is worth noting the need to continue the activity for development and effective functioning of the created educational and scientific-research environment for realization of supervision with social work students. The focus in this regard is the application of modern forms, methods and models of supervision in social work practical training, encouraging and motivating students to make optimal use of their possibilities for change, growth and development.

\section{Discussion and proposals for change and development}

The realization of supervision in the practical training of social work students in modern conditions is facing the challenge. In this regard, it is necessary to respond to the increasing importance of closer ties and the integration of theory and practice as a process of two-way transfer of values, knowledge skills and 


\begin{tabular}{|c|c|c|c|c|c|c|}
\hline \multirow{4}{*}{ Impact Factor: } & ISRA (India) & $=3.117$ & SIS (USA) & $=0.912$ & ICV (Poland) & $=6.630$ \\
\hline & ISI (Dubai, UAI & $=0.829$ & РИНЦ (Russia & $=0.156$ & PIF (India) & $=1.940$ \\
\hline & GIF (Australia) & $=0.564$ & ESJI (KZ) & $=8.716$ & IBI (India) & $=4.260$ \\
\hline & JIF & $=1.500$ & SJIF (Morocco & $=5.667$ & OAJI (USA) & $=0.350$ \\
\hline
\end{tabular}

experience in the context of the requirement for high quality education and social work education and provision of competent and qualified professionals for professional practice.

Practical training on social work is likely to be negative affected, if the supervision provided in its terms is characterized by deficits in certain aspects. They mainly relate to: organizational, methodological and resource provision; preparation and qualification of supervisors (university professor and mentor-social worker); informing and motivating students to make optimal use of the possibilities provided by supervision them to acquiring values, knowledge, skills and experience, integrating theory and practice, analysing difficulties and problems and overcoming them, correcting behaviour, achieving change and development. An important role in affirmation the importance of supervision for social work students in their practical training has partner relationships and support from staff of social services, departments or institutions and learning from his good experience of using the possibility of supervision to improve the quality and efficiency of the activity and professional development [23; 27].

Quantitative and qualitative analysis of the results of the study allows to present conclusions and proposals on creating conditions for positive attitudes towards students to participate in the supervision of social work practical training contributing to their development.

It is necessary to adopt and apply standards for supervision of the practical training of social work students with contributions in certain fields. Among them stand out: improving the quality and effectiveness of practical training; optimizing the learning process and assimilation of good practical experience; stimulating the students to use the possibilities of supervision in the process of practical training and in their future professional realization.

From substantially importance is creation of suitable organization and planning in the conduct of supervision, with a focus on the responsibility of both parties for preliminary preparation and participation; technological and methodological provision of the realized supervision, which contributes to building a positive working relationship.

A leading factor for the realization of quality and effective supervision in the practical training of social work students is the formation of environment and conditions, which encourages partnership, active and motivated learning of knowledge, skills and experience. Its important component is the integration of theory and practice, management of learning processes and the acquisition of practical experience based on the identification of achieved progress and development.

The education, qualification, competence, experience and professionalism of the supervisor are one of the important factors for formation a positive working relationship and a style of interaction with certain characteristics. In their scope is includes: trust; focused on working process and respectable tone and atmosphere of communication; adequate use of the possibilities of the types of power relationships in the supervision process; implementing an individual and respecting personal and human dignity approach; manifestation of sensitivity to differences of cultural and other nature; non-discriminatory and nonoppressive behaviour and relationships.

From essential importance to implement supervision that contributes to quality and effective practical training in social work is to provide conditions for stimulating and developing skills to analyse problems and situations, maintaining effective feedback, developing reflexive and critical thinking in supervised students.

The supervision in social work practical training requires the development of professional thinking and the use of an analytical approach in interpreting the problems of the clients/users of social services and in the practicing. This provides a possibility of students to show sensitivity to their own and clients/users of social services thoughts, feelings, experiences and behaviours, and to stated readiness to take action for change and development.

The choice of a model of supervision in the practical training of social work students is determined depending on its capabilities to achieve high quality and efficiency and to contribute to the realization of the purposes of the learning practice in certain fields and of the education in the specialty. In this regard, the results of the research reveal presence of the highest relative share of expressed respondents' positive attitudes towards a model of supervision in the practical training on social work, which in the technological, organizational and methodological aspect includes the resources of the university professor of learning practice and of the mentor-social worker (model of co-supervision). Respondents' positions are that this model has the possibilities for answer in the highest extent of educational needs, and provision a broad foundation for support, acquiring of values, knowledge, skills and learning good practice. The model is characterized by the potential and resources to create conditions for value, and cognitive, professional and personal development; insurance of appropriate quality and efficiency of both the supervision process, as well as for realization of learning practice in different social work professional fields.

To compensate for the limitation of the research, we intend to study the opinions and attitudes of those who perform the function and role of supervisors to implementation of supervision in the practical training of students in social work. 


\begin{tabular}{|c|c|c|c|c|c|c|}
\hline \multirow{4}{*}{ Impact Factor: } & ISRA (India) & $=3.117$ & SIS (USA) & $=0.912$ & ICV (Poland) & $=6.630$ \\
\hline & ISI (Dubai, UAI & $=0.829$ & РИНЦ (Russia & $=0.156$ & PIF (India) & $=1.940$ \\
\hline & GIF (Australia) & $=0.564$ & ESJI (KZ) & $=8.716$ & IBI (India) & $=4.260$ \\
\hline & JIF & $=1.500$ & SJIF (Morocco & $=5.667$ & OAJI (USA) & $=0.350$ \\
\hline
\end{tabular}

\section{Conclusion}

Supervision is one of the significant components of the social work practical training, which underlie the formation and development professional competence, good practical experience and professional-personality qualities of students. Its function and role successfully to realized, when sustained positive attitudes towards the conduct of supervision are formed in the student. The supervision of practical training in social work should be based on a clear conceptual and technological justification and normative, organizational and methodologically relevant inclusion in Bachelor's and Master's social work education programs. Applying this approach has potential and possibilities to make a significant contribution to improve the quality and effectiveness of the practical and overall educational preparation of social work students. In the contemporary conditions in Bulgaria, there is an urgent need to step up the activity and the efforts of the academic and professional community of social workers to promote and affirmation the place, role and function of supervision in social work education and in the field of social activities. The presented research is part of the stated activities we hope to continue.

\section{References:}

1. Ajduković, M., \& Cajvert, L. (2003). The Development of Social Work Supervision in Countries in Transition: Reflections from Croatia and Bosnia - Herzegovina. Social Work in Europe, 10(2), 11-22.

2. Ajdukovic, M., Cajvert, L., Judy, M., Knopf, W., Kuhn, H., Madi, K., \& Voogd, M. (2015). ECVision. Supervision and Coaching in Europe: Concepts and Competences. Die Wiener Volkshochschulen GmbH, Vienna 2015. Retrieved from: www.anse.eu/ecvision/products

3. Australian Learning and Teaching Council (2010). A guide to supervision in social work field education. (Revised edition). Strawberry Hills, NSW: Australian Learning and Teaching Council.

4. Beddoe, E. (2000). The supervisory relationship. In L. Cooper, L., \& L. Briggs (Eds.). Fieldwork in the Human Services. New South Wales: Allen and Unwin, 41-42.

5. Beddoe, L. (2015). Social work supervision for changing contexts. In L. Beddoe \& J. Maidment (Eds.). Supervision in social work: Contemporary issues. London: Routledge, 8295.

6. Bennett, C. S. (2008). Attachment-informed supervision for social work field education. Clinical Social Work Journal, 36(1), 97-107. http://dx.doi.org/10.1007/s10615-007-0135-z

7. Bennett, S. (2008). The interface of attachment, transference, and countertransference: Implications for the clinical supervisory relationship. Smith College Studies in Social Work, 78(2-3), 301-320. https://doi.org/10.1080/ 00377310802114635

8. Bennett, S., Mohr, J., BrintzenhofeSzoc, K., \& Saks, L. (2008). General and supervision- specific attachment styles: Relations to student perceptions of social work field supervisors. Journal of Social Work Education, 44(2), 75-94. https://doi.org/10.5175/JSWE.2008.200700016

9. Bennett, S., Mohr, J., Deal, K. H., \& Hwang, J. (2013). Supervisor attachment, supervisory working alliance, and affect in social work field instruction. Research on Social Work Practice, 23(2), 199-209. http://dx.doi.org/10.1177/10497 31512468492

10. Bogo, M. (2015). Field Education for Clinical Social Work Practice: Best Practices and Contemporary Challenges. Clinical Social Work Journal, 43(3), 317-324. DOI: 10.1007/s10615015-0526-5

11. Brodie, I., \& Williams, V. (2013). Lifting the lid: Perspectives on and activity within student supervision. Social Work Education, 32(4), 506522. https://doi.org/10.1080/02615479.2012.67 8826

12. Cajvert, L., Branković, D., \& Grbo, I. (2007). Guide for postgraduate master studies, Supervision and Management in Social Work. Banja Luka: Sarajevo.

13. Cleak, H., \& Smith, D. (2012). Student satisfaction with models of field placement supervision. Australian Social Work, 65(2), 243258. https://doi.org/10.1080/0312407X.2011.572981

14. Crockett, K. (2007). Counselling supervision and the production of professional selves. Counselling and Psychotherapy Research, 7(1), 19-25. https://doi.org/10.1080/14733140601140402

15. Davys, A. (2007). Active participation in supervision: A supervisee's guide. In D. Wepa (Ed.). Clinical supervision in Aotearoa/New 


\begin{tabular}{|c|c|c|c|c|c|c|}
\hline \multirow{4}{*}{ Impact Factor: } & ISRA (India) & $=3.117$ & SIS (USA) & $=0.912$ & ICV (Poland) & $=6.630$ \\
\hline & ISI (Dubai, UAE & $=0.829$ & РИНЦ (Russia & $=0.156$ & PIF (India) & $=1.940$ \\
\hline & GIF (Australia) & $=0.564$ & ESJI (KZ) & $=8.716$ & IBI (India) & $=4.260$ \\
\hline & JIF & $=1.500$ & SJIF (Morocce & $=5.667$ & OAJI (USA) & $=0.350$ \\
\hline
\end{tabular}

Zealand: a health perspective. Auckland, New Zealand: Pearson Education New Zealand.

16. Davys, A., \& Beddoe, L. (2000). Supervision of students: a map and a model for the decade to come. Social Work Education, 19 (5), 437-449. https://doi.org/10.1080/026154700435968

17. Davys, A., \& Beddoe, L. (2009). The Reflective Learning Model: Supervision of Social Work Students. Social Work Education, 28(8), 919933.

https://doi.org/10.1080/02615470902748662

18. Edmond, T., Megivern, D., Williams, C., Rochman, E., \& Howard, M. (2006). Integrating evidence based practice and social work field education. Journal of Social Work Education, 42(2),

377-396. http://dx.doi.org/10.5175/JSWE.2006.20040411 5

19. Ellis, G. (2000). Reflective learning and supervision. In L. Cooper \& L. Briggs (Eds.), Fieldwork in the human services: Theory and practice for field educators, practice teachers and supervisors. St. Leonards, Australia: Allen \& Unwin.

20. Fortune, A. E., McCarthy, M., \& Abramson, J. S. (2001). Student learning processes in field education: Relationship of learning activities to quality of field instruction, satisfaction, and performance among MSW students. Journal of Social Work Education, 37(1), 111-124. https://doi.org/10.1080/10437797.2001.107790 40

21. Gould, N. \& Baldwin, M. (Eds.) (2016). Social Work, Critical Reflection and the Learning Organization. Abingdon: Routledge.

22. Hees, G. van, \& Geißler Piltz, B. (Eds.). (2010). Supervision meets Education. Supervision in the bachelor of Social Work in Europe. Maastricht: CESRT Research Centre Social Integration, Faculty of Social Work, Zuyd University.

23. Holosko, M., \& Skinner, J. (2015). A call for field coordination leadership to implement the signature pedagogy. Journal of Human Behavior in the Social Environment, 25(3), 275-283. https://doi:10.1080/10911359.2015.1005519

24. Jones, M. (2004). Supervision, learning and transformative practices. In N. Gould \& M. Baldwin (Eds.). Social work, critical reflection and the learning organization. Aldershot, England: Ashgate.

25. Kadushin, A., \& Harkness, D. (2002). Supervision in Social Work. New York: Columbia University Press.

26. Ledwith, M. (2007). Reclaiming the radical agenda: a critical approach to community development. Concept, 17(2), 8-12.

27. Marc, C., Makai-Dimeny, J., \& Oşvat, C. (2014). The social work supervisor: Skills, roles, responsibilities. Bulletin of the Transilvania
University of Braşov, 7(1), 221-230. Retrieved from

http://webbut.unitbv.ro/BU2014/Series\%20VII/ BULETIN\%20VII\%20

28. McSweeney, F., \& Williams, D. (2018) Social care students' learning in the practice placement in Ireland. Social Work Education 37(5), 581596.

https://doi.org/10.1080/02615479.2018.145 0374

29. Mehandzhiyska, G. (2008). Supervision in social work. Support, guidance and development of helping professionals. Sofia: East-West Publishing House.

30. Noble, C. (2011). Field education: supervision, curricula and teaching methods. In C. Noble \& M. Henrickson (Eds.). Social work field education and supervision across Asia Pacific. Sydney, Australia: Sydney University Press, 322.

31. Nunev, S. (2014). Supervision in social work with students and models for its implementation. HASSACC: Human and Social Sciences at the Common Conference, Section Social Science, Families, Work, Activism, Lifestyle Choices, 2(1), 17-21

32. Nunev, S. (2014). Supervision practical training problems with social work students. Trakia Journal of Sciences, 12(1), 461-466.

33. Nunev, S. (2015). Attitudes of the students towards the conduct of supervision in their practical training in social work. Journal of Education, Psychology and Social Sciences, 3(2). Retrieved from http://www.scipub.com/archive/?vid=1 \&aid=2\&kid=10302-3

34. Nunev, S. (2015). Guide for Practical Training in Social Work. Ruse: Publishing house of University of Ruse "Angel Kanchev".

35. Nunev, S. (2015). Supervision with social work students - an important factor for the interaction between theory and practice. Social Work Education in Europe: towards 2025. Milan, Italy, 29th June - 2nd July 2015. European Association of Schools of Social Work. Abstract book, p. 350. Author index, p. 381.

36. Petrova-Dimitrova, N. (2014). Supervision in Social Work. Sofia: Veda Slovena-JG Publishing House.

37. Ross, E., \& Ncube, M. (2018). Student Social Workers' Experiences of Supervision. The Indian journal of social work, 79(1), 1940-2013. https://doi.org/10.32444/IJSW.2018.79.1.31-54

38. Salmon, H. (1997). Evaluating and Assessing Community Work Students. In Briscoe, C., \& Thomas, D (Eds.) Community Work: Learning and Supervision. National Institute Social Service Library, No. 32. London: George Allen and Unwin. 


\begin{tabular}{|c|c|c|c|c|c|c|}
\hline \multirow{4}{*}{ Impact Factor: } & ISRA (India) & $=3.117$ & SIS (USA) & $=0.912$ & ICV (Poland) & $=6.630$ \\
\hline & ISI (Dubai, UAE & $=0.829$ & РИНЦ (Russia & $=0.156$ & PIF (India) & $=1.940$ \\
\hline & GIF (Australia) & $=0.564$ & ESJI (KZ) & $=8.716$ & IBI (India) & $=4.260$ \\
\hline & JIF & $=1.500$ & SJIF (Morocce & $=5.667$ & OAJI (USA) & $=0.350$ \\
\hline
\end{tabular}

39. Tierney, H. (2011). Mapping Fieldwork and Supervision Practice: Part 1. Youth Studies Ireland, 6(1), 18-33.

40. Vassos, S., Harms, L., \& Rose, D. (2018). Supervision and social work students: relationships in a team-based rotation placement model. Social Work Education, 37(3), 328-341. https://doi.org/

10.1080/02615479.2017.1406466
41. Webber, R. (1999). Is there a difference between bungee jumping and field supervision? Paper presented to the HERDSA Annual Conference. Melbourne, 12-15 July, 1999.

42. White, V., \& Queener, J. (2003). Supervisor and Supervisee Attachments and Social Provisions Related to the Supervisory Working Alliance. Counsellor Education \& Supervision, 42(3), 203-218. https://doi.org/10.1002/j.1556-6978. 2003.tb01812.x 